\title{
Configuration of Organizational Capability to Enhancing Service Performance and Impact on Sustainable Local Enterprise Water Services
}

\author{
Nur Afifah, ${ }^{*}$ and Ilzar Daud ${ }^{2}$ \\ ${ }^{1,2}$ Management Study Program, Faculty of Economics and Business, Universitas Tanjungpura, 78124 Pontianak, West Kalimantan, \\ Indonesia
}

\begin{abstract}
Objective - Configuration of organizational capability plays a very important role in creating service performance, and superior and sustainable company performance. The purpose of this study is to propose a conceptual to explain the role between configuration of organizational capability to service performance and its impact on sustainable local enterprise water services in West Kalimantan, Indonesia.

Methodology/Technique - The data was collected from 100 managers at the local enterprise water service in West Kalimantan Indonesia using a purposive sampling method. The analysis tool used was structural equation modeling partial least square (SEMPLS).

Findings - The model in this study was confirmed by the data collected which shows the importance of configuring organizational capability to improve both service performance and sustainability of the local enterprise water services in West Kalimantan. The classification of configuration organizational capability in local enterprise water services includes human capability, information technology capability, system capability, and dynamic capability.

Novelty - Most of the previous research focus on western countries. Therefore, this research is novel as it is carried out in the context of developing countries, particularly in local enterprise water services in West Kalimantan, Indonesia.

Type of Paper: Empirical.
\end{abstract}

Keywords: RBV; Configuration Organizational Capability; Service Performance; Sustainable Local Enterprise Water Service.

JEL Classification: M20, M29.

\section{Introduction}

The study of the creation of sustainable excellence is an interesting area of study for marketing and management experts, because it is very influential on improving sustainable company performance (Barney, 1991; Ismail et. al., 2012; Leonidou et. al., 2013).

\footnotetext{
* Paper Info: Revised: December 17, 2018

Accepted: March 16, 2019

* Corresponding author: Nur Afifah

E-mail: afifahnur_fe@yahoo.com

Affiliation: Faculty of Economic and Business, Universitas Tanjungpura, Indonesia.
} 
To obtain sustainable performance, companies must develop strategies that exploit their own strengths and avoid internal weaknesses, respond to environmental opportunities and neutralize environmental threats, and local enterprise water services in West Kalimantan, Indonesia. An approach based on RBV states that in order to achieve sustainable excellence, in addition to resources, companies must also have the capability to obtain resources and manage them in accordance with their market environment (Morgan, 2012). Hence, this research seeks to provide an alternative for managing local enterprise water services in West Kalimantan Indonesia. Thus, to increase public value and create sustainability, companies must configure organizational capability, which includes classifying their capabilities in order to create service performance for customers. This is because the sources of competitive advantage include aspects of resources and capabilities (Fong et. al., 2014; Lage et. al., 2009). Meanwhile, according to Day (1994), capability refers to the set of skills and accumulation of a number of knowledge that enables a company to use its resources in an effort to generate added value and competitiveness.

Some opinions state that capability must be owned so that the company can improve service performance and ultimately improve sustainable company performance, including human capital, organizational capital, relational capital, and informational capital (Griffit, 2010), system capabilities (Ismail et. al., 2012), IT Capability (Dawe et. al., 2012; Pee \& Kankanhalli. 2015), as well as human capacities, process capabilities, and technology capabilities (Beevers, 2000). In addition to being able to survive and adjust in a dynamic environment, dynamic capability is needed (Newhert, 2005; Teece, 2007; Wu, 2010). Therefore, this study aims to propose a conceptual model to explain the role of configuration organizational capability to service performance and its influence on sustainable local enterprise water services in West Kalimantan, Indonesia. It also aims to classify the capabilities based on resource-based theoretical concepts (RBV) and contingency theory that must be owned by local enterprise water services in West Kalimantan, Indonesia.

\section{Literature Review and Hypothesis Development}

\subsection{The Conceptual Base Configuration Organizational Capability}

Organizational capability is a concept that has been used to summarize the insight into the theory of resource-based high-performance companies. Capability incorporates all company assets both tangible and intangible, competencies, organizational processes, company attributes, information and everything controlled by the company that enables the company to understand and implement strategies to improve efficiency and effectiveness. In other words, capability is a special type of resource that aims to increase the productivity of other resources owned by the company (Makadok 2001; Kozlenkova, 2014), and are closely related to the company's competitive advantage (Kaleka \& Morgan, 2017). Derived from those concepts, the local enterprise water services is believed to be able to produce superior customer value through the quality of services given to customers that have an impact on company performance, hence, a strategy for configuration organizational capability is very important (Furrer et. al., 2008; López et. al., 2011).

Configuration of organizational capability aims to classify the capabilities possessed by the company in creating sustainable performance. Several studies state that to create excellence, local enterprise water services must be able to optimize its capabilities, such as human capability, IT capability, system capability. Those are part of the strategic resources that must be optimized (Beevers, 2000; Wu, 2010; Dawes et. al., 2012; Bekkers et. al., 2013; Pee \& Kankanhalli. 2015; Afifah \& Ilzar, 2017).

Human capability itself is defined as the skills and knowledge owned by employees (Hunt, 2000), and is very influential for companies in achieving service performance (Griffith \& Lusch, 2007; Griffith et. al., 2010). Meanwhile, IT capability is defined as information technology that can link knowledge to everyone within an organization and is very important for achieving superior performance in services (Teece et. al., 1997, Song et. al., 2005; Furrer et. al., 2008; Son et. al., 2014). System capability can be defined as a business process and procedure (Ray et. al., 2004) which is an action of a company to achieve its business goals. Capability systems also have a role in creating sustainable excellence (Ismail et. al., 2012). However, 
in this study, the author considers dynamic capability because dynamic capability is an important requirement of the public sector to adapt to changes in the external environment (Newhert, 2005; Teece, 2007; Wu, 2010).

Therefore, the survival of a company depends on the application of strategies that maximize internal strength by overcoming internal weaknesses. This is because a sustainable competitive advantage may not last forever due to unexpected environmental changes, for which there is a need for organizational capability configuration (Eisenhardt \& Martin, 2000; Furrer et. al., 2008; López et. al., 2011).

\subsection{The Conceptual Base Service Performance}

Sustainable competitive advantage is achieved when companies implement value creation strategies that are based on unique resources, capabilities and competencies. The most effective sustainable achievement is to use the company's capability. The service industry plays a very important role in the economy of a country (Lovelock, 2012). In today's highly competitive and global environment, providing quality and competitive services is a part of crucial strategy for the success and survival of the company (Munhurrun et. al., 2010). Likewise, a company is expected to be able to provide quality services and create public value (Agbor, 2011; Lykal \& Celebi, 2016). For this reason, companies must be able to allocate the resources and strategic capacities available to them (Bekkers et. al., 2013; Pee \& Kankanhalli, 2015).

The existence of good service performance of a company is indispensable for the improvement of the profitability and survival of the company.

\subsection{Hypothesis Development}

Sustainable local enterprise water services are achieved when companies are able to implement value creation strategies based on unique resources, capabilities and competencies. Therefore, the survival of a company depends on the application of strategies that maximize internal strength by overcoming internal weaknesses because sustainable competitive advantage may not last forever due to unexpected environmental changes, for which there is a need for configuration organizational (Furrer et. al., 2008; López et. al., 2011).

As discussed above, several studies state that the capability classifications can improve sustainable enterprises, including human capabilities, IT capability, system capabilities and dynamic capabilities (Eisenhardt \& Martin, 2000; Newhert, 2005; Griffith et. al., 2010; Wu, 2010; Perez et. al., 2007; Ismail et. al., 2012; Son et. al., 2014; Pee \& Kankanhali, 2015). Therefore, the hypotheses are proposed:

H1: Configuration of organizational capability influences service performance.

$\mathrm{H} 2$ : Configuration of organizational capability has an effect on the sustainability of local enterprise water services.

H3: Service performance affects the sustainability of local enterprise water services.

\section{Research Methodology}

This explanatory research examines 100 managers at the local enterprise water service in West Kalimantan, Indonesia. The participants were selected using a purposive sampling method. The analytical tool used was the partial least square (SEMPLS) modeling equation. Before testing the hypotheses, the variables for configuration of organizational capability was carried out using the literature study method.

The variables of configuration capability with indicators of human capability include IT capability, system capability and dynamic capability. Service performance variables with quality indicators include, physical environment quality and outcome quality. The variables of sustainable local enterprise water services indicators include financial aspects, operational aspects, service aspects and HR aspects. 


\section{Research Findings}

To test the hypotheses, the researcher used statistical $\mathrm{T}$ value test in which a 95\% confidence interval must be higher than 1.96 or the $\mathrm{P}$ value must be less than 0.05 . This will mean that the effect is significant. The results of the hypothesis testing are presented in Table 1 below.

Table 1. Hypothesis Testing Results

\begin{tabular}{|c|c|c|c|c|}
\hline Causality Relations & $\begin{array}{c}\text { Path } \\
\text { Coefficient }\end{array}$ & T-Statistic & p-Value & Information \\
\hline Configuration of capability $\rightarrow$ Service performance & 0,146 & 1,596 & 0,000 & Significant \\
\hline Configuration of capability $\rightarrow$ Sustainable LEWS & 0,280 & 3,344 & 0,001 & Significant \\
\hline Services performance $\longrightarrow$ Sustainable LEWS & 0,363 & 3,248 & 0,000 & Significant \\
\hline
\end{tabular}

The results of the statistical tests show that all of the hypotheses proposed in this study have a significant effect on the $p-V a l u e>0.05$. This shows that in order to achieve sustainable local enterprise water service, the companies must configure the organizational capability to improve service performance which ultimately impacts the sustainability of local enterprise water services in West Kalimantan.

\section{Discussion}

The results of the literature review explain the configuration of organizational capability is used to classify the capabilities possessed by the company to increase company performance. In the local enterprise water service, the sources of capability include human capability, IT capability, system capability and dynamic capability. The results of this study support the theory developed by some experts that the sources of competitive advantage include aspects of resources and capabilities. However, resources and capabilities will not be valuable if they are not applied and integrated (Lages et. al., 2009; Fong et. al., 2014; Pee \& Kankanhali, 2015). Therefore, there is a need for configuration of organizational capability so that the resources become valuable and useful (Varga \& Lusch, 2011), which enables the company to improve service performance and sustainability.

The configuration of organizational capability is important for service performance, and affects the sustainability of local enterprise water services in West Kalimantan, Indonesia. The results of this study are consistent with the results of previous studies by Furrer et. al. (2008) and López et, al. (2011). Thus, this study suggests that company leaders must be able to allocate, integrate and utilize the resources (tangible, intangible, and capabilities) owned by the company. This will enable them to create sustainable performance because sustainable excellence can be achieved when their companies implement value creation strategies based on resources, unique capabilities and competencies.

\section{Conclusion}

The findings of this study affirm that configuration of organizational capability influences service performance and its impact on the sustainability of local enterprise water services in West Kalimantan, Indonesia. Theoretically, these findings contribute to the implementation of the RBV concept and contingency theory in the management of public organizations. Meanwhile, the survival of a company depends on the application of strategies that maximize internal strength by overcoming internal weaknesses. Given that sustainable competitive advantages may not last forever due to unexpected environmental changes, configuration of organizational capability is extremely important. 


\section{References}

Afifah Nur and Daud Ilzar. (2017). Antecedent and Consequent Customer Company Identification to Relationship Marketing in PDAM Tirta Khatulistiwa Pontianak, West Kalimantan Indonesia. Journal of Management and Marketing Review, 2(2), 38-43.

Agbor M, J. (2011). The Relationship between Customer Satisfaction and Service Quality: A Study of Three Service Sectors in Umea, Umea University.

Barney, J. B. (1991). Firm Resources and Sustained Competitive Advantage. Journal of Management, 17 (1), $99 \mathrm{e} 120$.

Beevers Richard. (2000). Northern Housing Consortium, Webster's Ropery, Customer Service Excellence in the Public Sector.

Bekkers, V. J. J. M., Tummers, L. G., Stuijfzand, B. G and Voorberg, W. (2013). Social Innovation in the Public Sector: An Integrative Framework. LIPSE Working Papers 1 (Rotterdam: Erasmus University Rotterdam).

Chiun Lo-May, Mohamad Abang Azlan, Ramayah T and Chai Wang Yin. (2015). Examining the Effects of Leadership, Market Orientation and Leader Member Exchange (LMX) on Organisational Performance. Inzinerine EkonomikaEngineering Economics 26(4): 409-421.

Dawes, S. S., Gharawi, M. A. and Burke, G. B. (2012). Transnational Public Sector Knowledge Network: Knowledge and Information Sharing in a Multi-dimensional Context. Government Information Quarterly, 29(1), S112-S120.

Day, G. S. (1994). The Capabilities of Market Driven Organizations. The Journal of Marketing. 37-52.

Eisenhardt, K. M. and Martin, J. A. (2000). Dynamic Capabilities: What are They? Strategic Management Journal, 21 (10e11), 1105e1121.

Fong, S. F., Lo, M. C. and Ramayah, T. (2014). New Product Development and Performance in the Banking Industry. Asia Pacific Journal of Management Research and Innovation, 10(4), 305-321.

Furrer Oliver, Sudharshan D., Howard Thomas and Alexandre Tereza Maria. (2008). Resource Configurations, Generic Strategies and Firm Performance. Journal of Strategy and Management, 1(1), 15-40.

Griffith, D.A. and Lusch, R.F. (2007). Getting Marketers to Invest in Firm-specific Capital; Journal of Marketing, 7(1), 129-145.

Griffith A David, Yalcinkaya Goksel and Calantone J. Roger. (2010). Do Marketing Capabilities Consistently Mediate Effects of Firm Intangible Capital on Performance across Institutional Environments? Journal of World Business, 45, 217-227.

Hunt, S. D. (2000). A General Theory of Competition. Thousand Oaks, CA: Sage Publications.

Ismail Ismadi Alimin, Rose Che Raduan, Ili Jegak and Abdullah Haslinda. (2012). The Relationship Between Organizational Resources, Capabilities, System and Competitive Advantage. Asian Journal of Management, 17(1), 151173.

Kaleka, A. and Morgan, N. A. (2017). Which Competitive Advantage(s)? Competitive Advantage-market Performance Relationship in International Markets. Journal of International Marketing, 25(4), 25-49. doi:10.1509/jim.16.0058.

Kersten, W. and Koch, J. 2010. The Effect of Quality Management on the Service Quality and Business Success of Logisticsser- vice Providers. International Journal of Quality and Reliability Management, 27, 185-200.

Kozlenkova V Iriana, Samaha A Stephen and Palmatier W Robert. (2014). Resource-based Theory in Marketing. Journal of the Academic Marketing Science, 42, 1-21.

Lages, L. F., Silva, G. and Styles, C. (2009). Relationship Capabilities, Quality, and Innovation as Determinants of Export Performance. Journal of International Marketing, 17(4), 47-70.

Leonidou C. Leonida, Lenidou Constantions, Fotiadis A. Thomas and Zeriti Athina. (2013). Resources and Capabilities as Drivers of Hotel Environmental Marketing Strategy: Implications for Competitive Advantage and Performance. Tourism Management, 23, 94-110.

Lopez Gamero, M. D., Molina Azorin, J. E. and Claver Cortes, E. (2011). The Relationship between Managers' Environmental Perceptions, Environmental Management and Firm Performance in Spanish Hotels: A Whole Framework. International Journal of Tourism Research, 13(2), 141e163.

Lovelock. (2012). Market orientation and business performance: a framework for services organization. Thomson, South-Western.

Lyikal Ovgu Cidar \& Celebi Aysem. (2016). Investigating a quality of services in the public sector. Evidence from northing cyprus. Journal Economic and Social Development, 3 (2).

Makadok, R. (2001). Toward a synthesis of the resource-based and dynamic capability views of rent creation. Strategic Management Journal, 22 (5), 387-401. 
Morgan, N. A. (2012). Marketing and business performance. Journal of the Academy of Marketing Science, 40 (1), 102 -119 .

Munhurrun Prabha Ramseook, Bhiwajee Soolakshna D. Lukea, \& Naido Perunjodi. (2010). Service quality in the public service. International Journal of Management and Marketing Research 3 (1).

Newbert SL. (2005). New firm formation: a dynamic capability perspective. Journal Small Busniss Management, 43 (1), 55-77.

Newbert, S. L. (2008). Value rareness, competitive advantage, and performance: a conceptual-level empirical investigation of the resource-based view of the firm. Strategic Management Journal, 29 (7), $745 \mathrm{e} 768$.

Pee, L.G \& Kankanhalli. (2015). Interactions among factors influencing knowledge management in public sector organizations: A resource-based view. Goverment Information Quartely xxx-xxx.

Perez-Freije, J., \& Enkel, E. (2007). Creative tension in the innovation process: How to support the right capabilities. Eoropean Management Journal, 25 (1), 11-24.

Ray, G., Barney, J.B., \& Muhanna, W.A. (2004). Capabilities, business processes, and competitive advantage: choosing the dependent variable in empirical test of the resource-based view. Strategic Management Journal, 25 (1), $23 \mathrm{e} 37$.

Shekarchizadeh, A., Rasli, A., \& Tat, H. H. (2011). SERVQUAL in Malaysian Universities: Perspectives of International Students. Business Process Management Journal 17: 67-81.

Song, M., Droge, C., Hanvanich, S. \& Catalone, R. (2005). Marketing and technology resource complementary: an analysis of their interactions effect in two environmental contexts. Strategic Management Journal, 26, 259-76.

Son Insoo, Lee Dongwon, Lee Nam Jae, \& Chang Bong Young. (2014). Market perception on cloud computing initiatives in organizations: An extended resource-based view. Information \& Management Journal, 51, 653-669.

Teece, D., Pisano, G. \& Shuen, A. (1997). Dynamic capabilities and strategic management. Strategic Management Journal, 18, 509-33.

Teece DJ. (2007). Explicating dynamic capabilities: the nature and micro foundations of (sustainable) enterprise performance. Strategic Management Journal, 28, 1319-50.

Vargo SL and Lusch RF. (2011). It's all B2B and beyond: Toward a systems perspective of the market. Industrial Marketing Management, 40 (2), 181-187.

Wu Yu Lei. 2010. Applicability of the resource-base and dynamic capability views under environmental volatility. Journal of Business Research, 63, 27-31. 